\title{
The Influence of Demographic Characteristics of Greek Bank Employees on their Perceptions of Organizational Culture
}

\author{
Dimitrios Belias \\ (Corresponding author) \\ University of Thessaly, Karyes, Trikala, Thessalia, Greece \\ E-mail: dbelias@pe.uth.gr \\ Athanasios Koustelios \\ University of Thessaly,Karyes, Trikala, Thessalia, Greece \\ E-mail: akoustel@pe.uth.gr
}

Doi:10.5296/ijhrs.v4i1.5058ＵRL: http://dx.doi.org/10.5296/ijhrs.v4i1.5058

\begin{abstract}
The purpose of the present study was to reveal how demographic characteristics influence the perceptions of bank employees of organizational culture. The sample of the study consisted of 240 employees from Greek banking institutions, from different occupational positions. $60 \%$ of the employees were 31-40 years old followed by the categories 41-50 years old (20\%), up to 30 years old (10\%) and 51-60 years old (10\%). Most of the employees $(63.8 \%)$ had been working as bank employees for 6-15 years and the majority of them $(63.8 \%)$ had been working in the same bank for 6-15 years. The majority of the employees (59.6\%) were simple clerks, 29.2\% were supervisors and $11.3 \%$ were Managers or Assistant Managers. The assessment of organizational culture was performed with the Organizational Culture Assessment Instrument (OCAI) developed by Cameron and Quinn (2006). Results indicate that there is a significant difference in the perceptions of the subjects between the dominant current and the dominant preferred type of organizational culture. In addition, a statistically significant difference $(\mathrm{p}<0.01)$ was found between Managers and clerks on the one hand and Supervisors on the other hand in terms of both the dominant current and the dominant preferred type of organizational culture. Finally, employees' perceptions of the dominant current and the dominant preferred type of organizational culture were found to be affected by other demographical characteristics, like
\end{abstract}


age, total years of working in the same bank and total years of working in any bank. Future studies can extend the present work by examining additional parameters that affect employees' perceptions of organizational culture.

Keywords: Organizational Culture, Banking Sector, OCAI, Greece.

\section{Introduction}

It is widely acknowledged the difficulty in identifying a typology of organizational culture, since it is difficult to 'categorize' shared assumptions and beliefs of individuals. Organizational culture can be described as a group of basic assumptions (Schein 1986), shared values and norms (Deshpande \& Webster 1989; Ravasi and Schoultz 2006; Xiaoming \& Junchen 2012), that assists its members to cope with problems (Shein 1986), thus providing a smooth running of the company. According to Hofstede (1991), the behavior of an individual in the work place is influenced by three cultures: national, occupational and organizational. National culture involves the values that have been espoused by the family during childhood. Occupational culture is formed during school and professional life, and includes values and beliefs that are shared with other people. These values are mainly referred to "how things are done" in a specific profession (Deal and Kennedy 1982, in Jones 2008). While national culture is difficult to change during lifetime, occupational and organizational cultures are likely to change.

Deal and Kennedy (1982, in Jones 2008) categorize organizational culture in four types: The Tough-Guy, Macho culture: this type of culture is characterized by high stress work and employees value greatly their ability to handle high pressure. Taking high risks in order to achieve employees personal and company's goals is highly favored. Work Hard/Play Hard culture: this culture is customer oriented. It is characterized by high speed action in order to get quick results. High pressure is mainly derived by the quantity of the work load. Bet-Your-Company culture: this type is characterized by high risk but slow reward. Companies make risky but well planned investments. Process culture: in this culture, the stress is not high, since low risk investments are preferred. The key elements of this culture are precision, detail and technical perfection.

Denison's model of organizational culture describes a theory of culture linked to company's performance. First, information is collected from managers about their perceptions on the existent organizational culture. Afterwards, the collected information is processed using a two-dimensional model, highlighting the crucial issues of internal versus external focus and flexibility versus stability and their impact on performance and viability. Denison asserts that organizational culture can be described by four cultural traits: adaptability, mission, consistency, and involvement. Each trait is further described by three sub-dimensions: Adaptability: creating change, customer focus, organizational learning. Mission: strategic direction and intent, goals and objectives, vision. Consistency: core values, agreement, coordination and integration. Involvement: empowerment, team orientation, capability development (Denison et al. 2004).

Xenikou and Furnham (1996), recognize four types of organizational culture: 
Openness to change/innovation culture: in this type of culture, innovation and change are favored. The main characteristics of the culture are humanistic orientation, affiliation, achievement, self-actualization, task support and task innovation. Task-oriented organizational culture: the main focus on this culture is on the ways the company will be successful, including all the factors that will lead to that direction e.g. quality orientation and attention to detail. Bureaucratic organizational culture: it is a conservative type of culture characterized by centralized decision making. Competition/Confrontation organizational culture: the key concept of this type is perfectionism and is characterized by competition and goal orientation.

According to Cameron and Quinn (2006), there are four types of organizational culture: Hierarchical: is a well coordinated culture, where formal rules and policies maintain a smooth running organization. Market: is a competitive culture, where the glue that holds the organization together is winning. Clan: is a "friendly" culture, resembles the extension of family. It is characterized by loyalty to the firm and leaders are thought as mentors. Adhocracy: is a culture based on risk taking and innovation. It is characterized by a dynamic and creative workplace. Based on Cameron and Quinn (2006) typology, Belias and Koustelios (2013) studied the organizational culture of Greek banking institutions. It was found that the dominant organizational culture of the institutions were hierarchical while employees preferred the clan type.

Organizational culture is a social construction and has therefore been correlated to various demographic factors, like gender, age, years of working experience in general and in the specific institution, educational level and position held. More specifically, the observable values and norms adopted by an organization's employees are considered to influence their perceptions of one another and the interaction among them, as well as their problem solving and decision making (O' Reilly \& Chatman, 1996). In general, demographical diversity in organizations has been positively related to several benefits, like variance in perspectives and approaches to work provided by employees of different backgrounds, useful new information incorporated into decisions and responsiveness to changes (Thomas \& Ely, 1996; Donellon, 1993; Nemeth, 1992). Many researchers have supported the positive effects of demographic heterogeneity, via a "value-n diversity" hypothesis (Cox, Lobel \& McLeod, 1991). It should be noted, however, that other experts have come to the conclusion that heterogeneous work groups experience more difficulties in communication and are less socially integrated, while they feel less attached to their organization (O’ Reilly, Caldwell \& Barnett, 1989; Tsui, Egan \& O’Reilly, 1992).

Other researchers, like Turner, Oakes, Haslam and McGarty (1994) have come to the conclusion that in working frames where organizational membership is salient, demographic attributes are expected to be less salient. In particular, collectivistic types of organizational culture are likely to increase the salience of organizational membership as a social category, causing a corresponding decrease in the salience of demographic categories. However, Chatman, Polzer, Barsade, and Neale (1998) claim that interaction among demographically dissimilar people should be higher in collectivistic than in individualistic organizational cultures, since employees are perceived as part of the in-group.

Chen, Fosh and Foster (2008) found that bank employee's perceptions of 
organizational culture were influenced by various factors: type of bank, human relations practices, age, educational background and years of service. Kodzik (2009) supported that the ages of employees in a specific organization should be as diverse as race and gender. Salopek (2006) reported that a multigenerational workforce had major implications for organizations, while Crumpacker and Crumpacker (2007) recommended that managers should accept that employees are likely to bring their personal generational or age-based values to work.

The recent study of Allard (2010) explored among others the effect of employees' age and longevity on the relation between employee-organizational culture gap and performance, which is likely to affect an organization's overall objectiveness. According to the results, the relation between the employee-organizational culture gap and performance tended to be stronger for employees with more employee longevity, while employees' age did not seem to affect the direction or strength of that relation.

In an extension to our previous work, the purpose of the present study was to investigate the effect of age, working experience and position held on employees' perceptions of organizational culture. More particularly, it was hypothesized that the perceptions of younger participants about their organization's culture would be different from the ones of older ones. Additionally, it was hypothesized that there will be significant differences among the perceptions of Clerks, Managers and Supervisors. Finally, it was hypothesized that there will be significant differences between employees with more or fewer years of working in the same bank and employees with more or fewer years of working in any bank.

\section{Methods}

\subsection{Participants}

The sample of this study comprised employees of a certain bank in Greece. A total of 400 questionnaire sent by e-mail in their accounts at work. After a two months period, a total of 312 questionnaires were returned, giving a response rate of 70 per cent. Of these 240 questionnaires used in the final statistical analysis because the rest were half completed. They were 72 males (30\%) and 168 females (70\%). The employees ranged in age from 31-60 years $(\mathrm{M}=40.28, \mathrm{SD}=8.24)$. The majority of the participants $(50 \%)$ hold a university degree $(\mathrm{N}=120)$ while $20 \%$ of them $(\mathrm{N}=48)$ had also a postgraduate degree. Most of the employees (63.8\%) had been working as bank employees for 6-15 years and the majority of them (63.8\%) had been working in the same bank for 6-15 years. The majority of the employees (59.6\%) were simple clerks, 29.2\% were supervisors and $11.3 \%$ were Managers or Assistant Managers. The sample of the study is a group of young and educated people, which means that they have basic knowledge about the concept of this study adding accuracy to the findings (Acar and Acar 2012).

\subsection{Instruments}

In the present study the Organizational Culture Assessment Instrument (OCAI) survey was used (Cameron and Quinn 2006). The OCAI has been used to identify the organization's current culture. It has also been used to help the members of an organization to identify the 
culture they would like to be developed in order to match their future demands. It is based on the Competing Values Framework, referring to whether an organization has a predominantly internal or external focus and whether it strives for flexibility and individuality or stability and control (Cameron and Quinn 2006).

The OCAI consists of six questions (Dominant Characteristics, Organizational Leadership, Management of Employees, Organizational Glue, Strategic Emphases, Criteria of Success). Each question has four alternatives ( $\mathrm{A}=$ Clan, $\mathrm{B}=\mathrm{Adhocracy}, \mathrm{C}=$ Market, $\mathrm{D}=$ Hierarchy). Individuals completing the OCAI are asked to divide 100 points among the four alternatives, depending on the extent to which each alternative is similar to the organization being assessed. A higher number of points are to be given to the alternative that is most similar to the organization in question. Results of the OCAI survey are obtained by computing the average of the response scores for each alternative. Once scores are determined for all alternatives in both the Now and Preferred columns, they can be plotted to draw a picture of the organizational culture profile.

In order to be able to use the OCAI survey in the Greek environment permission was obtained and the questionnaire its self was translated in Greek in order to much the meaning of the initial questionnaire. According to Banville et al (2000), when a questionnaire is used in a sample that speak different language, it is important to follow translation and validation procedures in order to be accurate in the specific environment. Vallerand (as mentioned in Banville et al 2000), has suggested seven steps that are essential in cross cultural studies: a) preparation of preliminary translated versions of the questionnaire, b) evaluation of these versions by experts and preparation of the experimental version, c)pretest of the version, d)evaluation of the content and concurrent validity and g) establishing norms. In the present study, all seven steps were followed in order to apply OCAI instrument for the purposes of the research.

\subsection{Procedure}

The method chosen to assess organizational culture was that of self-completed questionnaires. Researchers informed all subjects that their participation was completely voluntary and the individual responses would be held in confidence. Quantitative data were analyzed using the Statistical Package for the Social Sciences (SPSS). Descriptive statistics, reliability analysis and paired t-tests were chosen as the most appropriate method for purposes of this study. The obtained data were tested for reliability with Cronbach's alpha. The Cronbach's alpha indicated that the data were reliable since they scored from 0.762 0.953 for the current organizational culture and $0.72-0.85$ for the future-preferred organizational culture (Table 1). 
Table 1. Chronbach's Alpha Reliability Test for each organizational type

\begin{tabular}{|c|c|c|}
\hline $\begin{array}{c}\text { Organizational } \\
\text { Culture Category }\end{array}$ & $\begin{array}{c}\text { Cronbach's alpha } \\
\text { for NOW }\end{array}$ & $\begin{array}{r}\text { Cronbach's alpha for } \\
\text { PREFERRED }\end{array}$ \\
\hline A & 0.809 & 0.726 \\
\hline B & 0.762 & 0.829 \\
\hline C & 0.857 & 0.854 \\
\hline D & 0.953 & 0.824 \\
\hline
\end{tabular}

\section{Results}

At first, the data were analyzed according to the OCAI scoring method. Thus, average scores were calculated for each of the organizational types $(A=C l a n, B=A d h o c r a c y$, $\mathrm{C}=$ Market, $\mathrm{D}=$ Hierarchy) in the Now (current) and Preferred (future) columns (Table 2). Latter these scores were plotted to draw a picture of the organizational culture profile of the Bank that was selected (Figure 1).

Table 2. Average scores for each organizational type

\begin{tabular}{|c|l|l|l|l|}
\hline \multirow{2}{*}{$\begin{array}{c}\text { Type of } \\
\text { Organizational } \\
\text { Culture }\end{array}$} & Mean & Std. Deviation & Mean & \multicolumn{2}{|c|}{$\begin{array}{r}\text { Organizational Culture } \\
\text { PREFERRED }\end{array}$} \\
\cline { 2 - 5 } & 19.5 & 7.42419 & 27.1667 & 5.52918 \\
\hline A & 17.6667 & 6.35755 & 25.3333 & 4.97133 \\
\hline B & 23.4167 & 7.81096 & 23.7500 & 7.14709 \\
\hline C & 39.4167 & 20.58100 & 23.7500 & 7.77338 \\
\hline D & & & & \\
\hline
\end{tabular}


Figure 1. Dominant current and preferred type of organizational culture

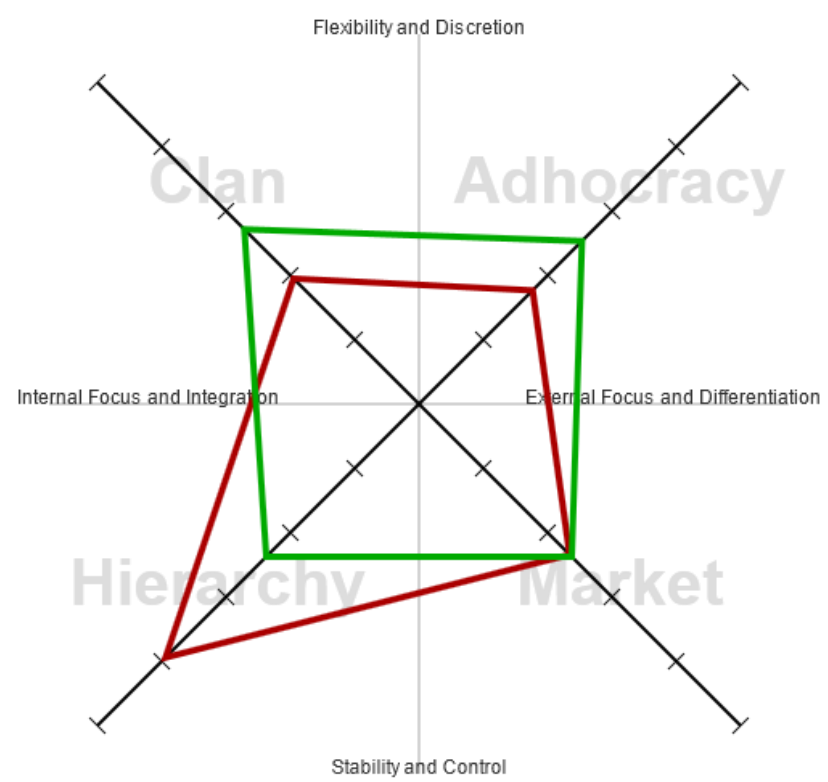

From Table 2 and Figure 1, it is obvious that the dominant current organizational culture is the Hierarchy and the least used organizational culture is the Adhocracy. For the preferred organizational culture the dominant culture is the Clan followed by the Adhocracy, the Market and the Hierarchy.

More specifically, the mean and standard deviation of each current type of organizational culture are presented for each question in Table 3. 


\section{Macrothink Institute ${ }^{\mathrm{TM}}$}

International Journal of Human Resource Studies

ISSN 2162-3058

2014, Vol. 4, No. 1

Table 3. Mean and Standard Deviation of each current type of organizational culture

\begin{tabular}{|c|c|c|c|c|c|c|c|c|c|c|c|c|}
\hline \multirow{3}{*}{$\begin{array}{l}\text { Type of } \\
\text { Organizational } \\
\text { Culture }\end{array}$} & \multicolumn{12}{|c|}{ NOW } \\
\hline & \multicolumn{2}{|c|}{ Question 1} & \multicolumn{2}{|c|}{ Question 2} & \multicolumn{2}{|c|}{ Question 3} & \multicolumn{2}{|c|}{ Question 4} & \multicolumn{2}{|c|}{ Question 5} & \multicolumn{2}{|c|}{ Question 6} \\
\hline & Mean & $\begin{array}{l}\text { Std. } \\
\text { Dev. }\end{array}$ & Mean & $\begin{array}{l}\text { Std. } \\
\text { Dev. }\end{array}$ & Mean & $\begin{array}{l}\text { Std. } \\
\text { Dev. }\end{array}$ & Mean & $\begin{array}{l}\text { Std. } \\
\text { Dev. }\end{array}$ & Mean & $\begin{array}{l}\text { Std. } \\
\text { Dev. }\end{array}$ & Mean & $\begin{array}{l}\text { Std. } \\
\text { Dev. }\end{array}$ \\
\hline A & 21,50 & 10,989 & 15,50 & 10,378 & 18,50 & 9,520 & 20,00 & 10,268 & 18,50 & 9,520 & 23,00 & 11,469 \\
\hline B & 19,50 & 10,617 & 15,50 & 6,888 & 20,00 & 10,510 & 16,00 & 8,907 & 18,50 & 8,977 & 16,50 & 10,033 \\
\hline C & 30,50 & 6,514 & 25,00 & 10,977 & 24,50 & 10,851 & 20,50 & 10,378 & 21,00 & 10,462 & 19,00 & 11,382 \\
\hline D & 28,50 & 18,754 & 44,00 & 20,996 & 37,00 & 22,318 & 43,50 & 24,449 & 42,00 & 25,272 & 41,50 & 24,653 \\
\hline
\end{tabular}

Furthermore, the mean and standard deviation of each preferred type of organizational culture are presented for each question in Table 4. 


\section{Macrothink Institute ${ }^{\text {TM }}$}

Table 4. Mean and Standard Deviation of each preferred type of organizational culture

\begin{tabular}{|c|c|c|c|c|c|c|c|c|c|c|c|c|}
\hline \multirow{3}{*}{$\begin{array}{l}\text { Type of } \\
\text { Organizational } \\
\text { Culture }\end{array}$} & \multicolumn{12}{|c|}{ PREFERRED } \\
\hline & \multicolumn{2}{|c|}{ Question 1} & \multicolumn{2}{|c|}{ Question 2} & \multicolumn{2}{|c|}{ Question 3} & \multicolumn{2}{|c|}{ Question 4} & \multicolumn{2}{|c|}{ Question 5} & \multicolumn{2}{|c|}{ Question 6} \\
\hline & Mean & $\begin{array}{l}\text { Std. } \\
\text { Dev. }\end{array}$ & Mean & $\begin{array}{l}\text { Std. } \\
\text { Dev. }\end{array}$ & Mean & $\begin{array}{l}\text { Std. } \\
\text { Dev. }\end{array}$ & Mean & $\begin{array}{l}\text { Std. } \\
\text { Dev. }\end{array}$ & Mean & $\begin{array}{l}\text { Std. } \\
\text { Dev. }\end{array}$ & Mean & $\begin{array}{l}\text { Std. } \\
\text { Dev. }\end{array}$ \\
\hline A & 25,00 & 7,432 & 25,50 & 6,119 & 27,50 & 11,480 & 29,50 & 10,851 & 27,50 & 6,033 & 28,00 & 7,499 \\
\hline B & 28,50 & 6,358 & 23,50 & 7,499 & 26,00 & 5,843 & 22,50 & 7,174 & 27,00 & 5,579 & 24,50 & 7,906 \\
\hline $\mathrm{C}$ & 27,50 & 9,306 & 22,00 & 12,516 & 24,00 & 10,219 & 24,00 & 7,015 & 24,00 & 7,015 & 21,00 & 9,184 \\
\hline $\mathrm{D}$ & 19,00 & 9,454 & 29,00 & 10,219 & 22,50 & 11,480 & 24,00 & 11,814 & 21,50 & 8,693 & 26,50 & 11,867 \\
\hline
\end{tabular}

The previous results indicate that there might be a difference in what the employees want the organizational culture to be from what the current organizational culture is. In order to test this hypothesis some Paired Samples T-Tests were conducted. The results in Table 5 indicate that there is a significant difference between the Now values from the Preferred in cultural types A, B and D ( $\mathrm{p}<0.01)$. As someone can see from the Table 5, types A and B have both scored significantly bigger in the Preferred row that the Now.

More specifically, employees seem to desire an increase of type A, so that the clan culture becomes stronger in the future comparison with the present. Furthermore, the mean of answers for type B increases from current to preferred culture, indicating that several employees desire an increase of adhocracy culture. Moreover, the mean of answers for type decreases from current to preferred culture, implying that employees desire a decrease of hierarchy culture (Table 5). 
Table 5. Differences between dominant current and preferred type of organizational culture

\begin{tabular}{|l|l|l|l|l|}
\hline \multicolumn{2}{|c|}{} & Mean & $\begin{array}{l}\text { Std. } \\
\text { Deviation }\end{array}$ & p \\
\hline \multirow{2}{*}{ Pair 1 } & A Now & 19.5000 & 7.42419 & 0.000 \\
\cline { 2 - 4 } & A Preferred & 27.1667 & 5.52918 & \\
\hline Pair 2 & B Now & 17.6667 & 6.35755 & 0.000 \\
\cline { 2 - 4 } & B Preferred & 25.3333 & 4.97133 & \\
\hline Pair 3 & C Now & 23.4167 & 7.81096 & 0.339 \\
\cline { 2 - 4 } & C Preferred & 23.7500 & 7.14709 & \\
\hline \multirow{2}{*}{ Pair 4 } & D Now & 39.4167 & 20.58100 & 0.000 \\
\cline { 2 - 4 } & D Preferred & 23.7500 & 7.77338 & \\
\hline
\end{tabular}

In order to test if the hypothesis that there is statistically significant difference in the believes of the employees, for the present and the preferred organizational culture of the bank they are working for, according to the position that these employees held, an ANOVA test was conducted. The test resulted that there is a difference in the believes and the preferences of the employees. Moreover, it was found that the order both the current and the preferred organizational culture that the employees sorted the cultures differs among them. The Managers and the Clerks believe that the current order of the four types is D, C, A, B, while the Supervisors think that is C, D, A, B (Table 6).

Table 6. Differences between the dominant current types of organizational culture depending on the position held by employees

\begin{tabular}{|c|c|c|c|c|c|}
\hline & Position held by the Employee & Mean & $\begin{array}{c}\text { Std. } \\
\text { Deviation }\end{array}$ & $\mathbf{F}$ & p \\
\hline \multirow[t]{3}{*}{ A Now } & Manager/Assistant Manager & 21.3889 & 4.00320 & \multirow[t]{3}{*}{24.179} & \multirow[t]{3}{*}{0.000} \\
\hline & Supervisor & 23.7738 & 6.39344 & & \\
\hline & Clerk & 17.0513 & 7.36563 & & \\
\hline \multirow[t]{3}{*}{ B Now } & Manager/Assistant Manager & 20.8333 & 2.40192 & \multirow[t]{3}{*}{38.264} & \multirow[t]{3}{*}{0.000} \\
\hline & Supervisor & 21.7024 & 3.89691 & & \\
\hline & Clerk & 15.0932 & 6.55653 & & \\
\hline \multirow[t]{3}{*}{ C Now } & Manager/Assistant Manager & 22.5000 & 2.40192 & \multirow[t]{3}{*}{35.330} & \multirow[t]{3}{*}{0.000} \\
\hline & Supervisor & 29.1786 & .70215 & & \\
\hline & Clerk & 20.7692 & 8.82088 & & \\
\hline \multirow[t]{3}{*}{ D Now } & Manager/Assistant Manager & 35.2778 & 8.80705 & \multirow[t]{3}{*}{34.319} & \multirow[t]{3}{*}{0.000} \\
\hline & Supervisor & 25.3452 & 10.45512 & & \\
\hline & Clerk & 47.0862 & 22.03414 & & \\
\hline
\end{tabular}

For the preferred organizational cultures the managers sorted the culture types with the following order C, B, D and A, where the corresponding order for the supervisors was C, B, A 
and D. When it comes to Clerks, they choose their preferred cultures as A, D, B, C. (Figure 2). Although the managers and the clerks chose the current state and the preferred with the same order, still there is statistically significant difference among those two, where the clerks give grater scores to the hierarchical culture (Mean 47.0862) and the other cultures have scores between 20.7692 and 15.0932 (Table 7).

Table 7. Differences between the dominant preferred types of organizational culture depending on the position held by employees

\begin{tabular}{|c|c|c|c|c|c|}
\hline & Position held by the Employee & Mean & $\begin{array}{c}\text { Std. } \\
\text { Deviation }\end{array}$ & $\mathbf{F}$ & p \\
\hline \multirow[t]{3}{*}{ A Preferred } & Manager/Assistant Manager & 21.8519 & .53376 & \multirow[t]{3}{*}{68.885} & \multirow[t]{3}{*}{0.000} \\
\hline & Supervisor & 23.6548 & 1.76801 & & \\
\hline & Clerk & 29.8893 & 5.56495 & & \\
\hline \multirow[t]{3}{*}{ B Preferred } & Manager/Assistant Manager & 26.0185 & 2.93568 & \multirow[t]{3}{*}{0.422} & \multirow[t]{3}{*}{0.656} \\
\hline & Supervisor & 25.5000 & 5.92220 & & \\
\hline & Clerk & 25.1224 & 4.77789 & & \\
\hline \multirow[t]{3}{*}{ C Preferred } & Manager/Assistant Manager & 27.6852 & 2.93568 & \multirow[t]{3}{*}{213.838} & \multirow[t]{3}{*}{0.000} \\
\hline & Supervisor & 31.6667 & 2.83397 & & \\
\hline & Clerk & 19.1317 & 5.01745 & & \\
\hline \multirow[t]{3}{*}{ D Preferred } & Manager/Assistant Manager & 24.4444 & 6.40513 & \multirow[t]{3}{*}{20.282} & \multirow[t]{3}{*}{0.000} \\
\hline & Supervisor & 19.1786 & 8.26115 & & \\
\hline & Clerk & 25.8566 & 6.79451 & & \\
\hline
\end{tabular}

Figure 2. Preferred types of organizational culture depending on the position held by employees

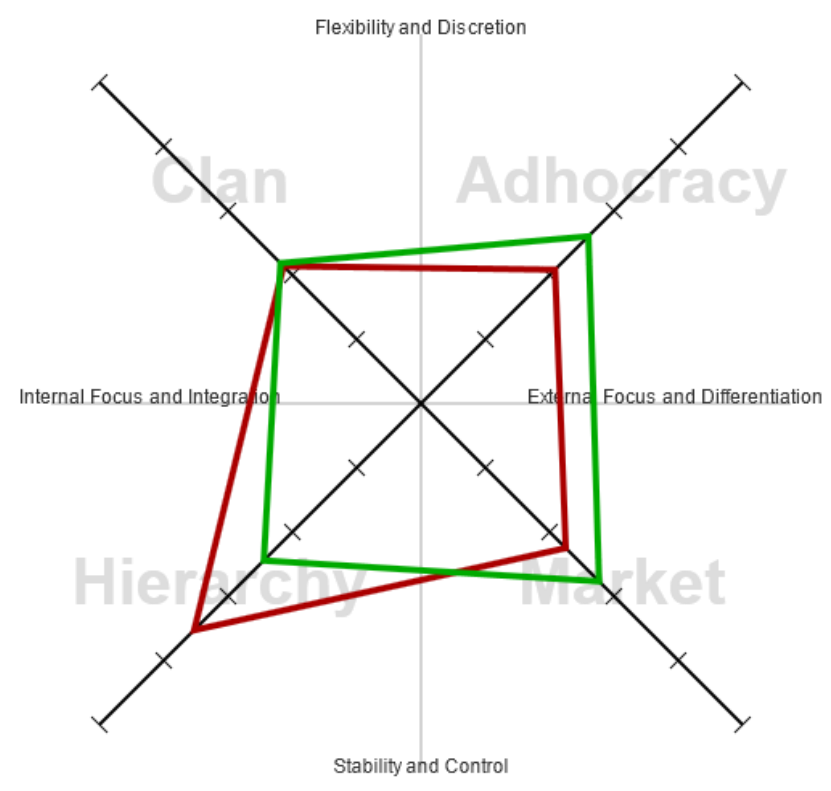




\section{Managers}

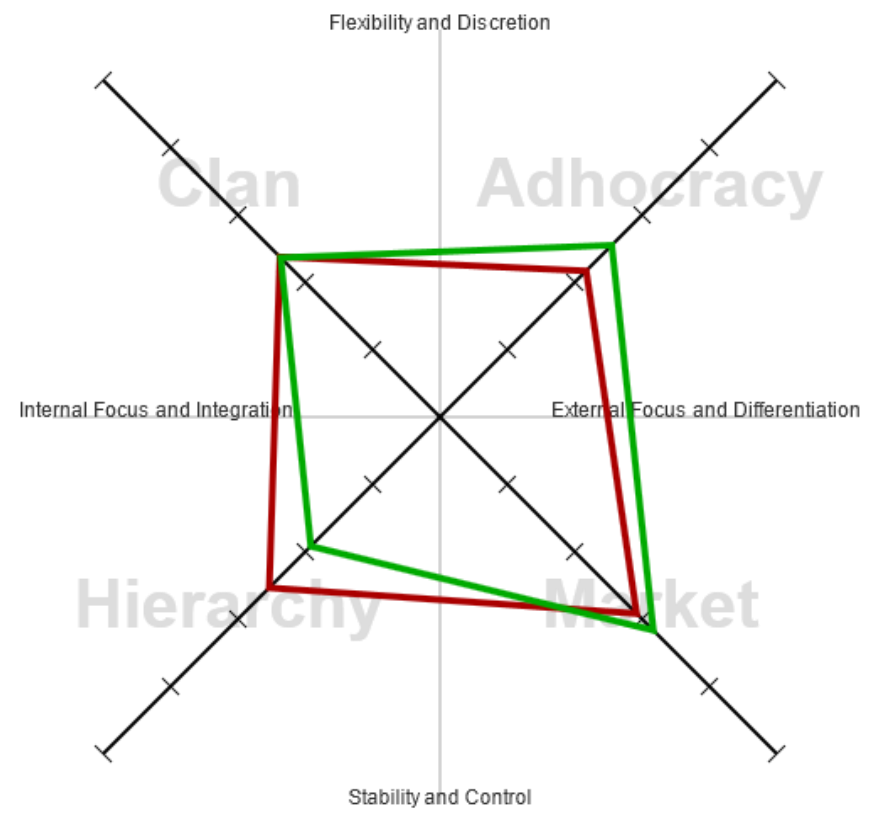

Supervisors

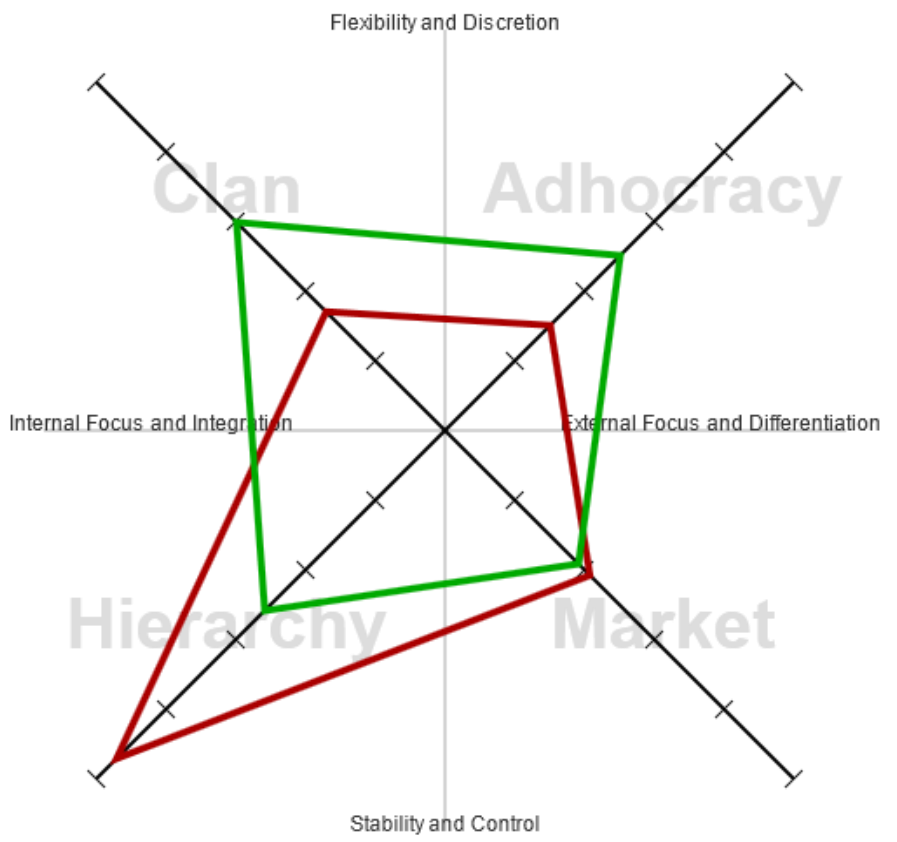

\section{Clerks}

Regarding the believes of the employees that participated in the survey it was found that there is statistically significant correlation (Pearson Correlation Coefficients) between the age of the participants and the current organizational culture that they chose, the total amount of years that these employees were working as employees in any bank and the current 
organizational culture that they chose and the total amount of years that they have been working in the same bank and the current organizational culture that they chose (Table 8).

For the current organizational cultures there is a positive correlation between the age and cultures $\mathrm{A}(\mathrm{r}=0.703$ and $\mathrm{p}=0.000<0.01), \mathrm{B}(\mathrm{r}=0.696$ and $\mathrm{p}=0.000<0.01)$ and $\mathrm{C}(\mathrm{r}=$ 0.639 and $\mathrm{p}=0.000<0.01)$ and a negative between the age and culture $\mathrm{D}(\mathrm{r}=-0.344$ and $\mathrm{p}=$ $0.000<0.01)$. This means that as age increases its value the cultures A through $\mathrm{C}$ increase their values too but the values of culture $\mathrm{D}$ decrease, which means that younger employees believe that the current culture is the hierarchical when the older (in age) employees believe that the current culture lies between cultures A, B and C (Table 8).

Similar results were found for the cultures A $(r=0.653$ and $p=0.000<0.01), B(r=$ 0.729 and $\mathrm{p}=0.000<0.01), \mathrm{C}(\mathrm{r}=0.533$ and $\mathrm{p}=0.000<0.01)$, and $\mathrm{D}(\mathrm{r}=-0.405$ and $\mathrm{p}=$ $0.000<0.01)$ and the total sum of years working in the same bank, where employees that haven't been work for long time at the bank that is studied believe that the current culture is the hierarchical when the employees that have been working in the bank for many years believe that the current culture lies between cultures A, B and C (Table 8).

For the total sum of years working in any bank there was found that there is a correlation with the cultures: $\mathrm{A}(\mathrm{r}=0.662$ and $\mathrm{p}=0.000<0.01), \mathrm{B}(\mathrm{r}=0.749$ and $\mathrm{p}=0.000<0.01), \mathrm{C}(\mathrm{r}$ $=0.566$ and $\mathrm{p}=0.000<0.01)$ and $\mathrm{D}(\mathrm{r}=-0.685$ and $\mathrm{p}=0.000<0.01)$, where the employees that haven't been work for long time believe that the current culture is the hierarchical and the employees that have been working for many years believe that the current culture lies between cultures A, B and C (Table 8).

Table 8. Correlations between dominant current types of organizational culture with employees' age, total years of working in the same bank and total years of working in any bank

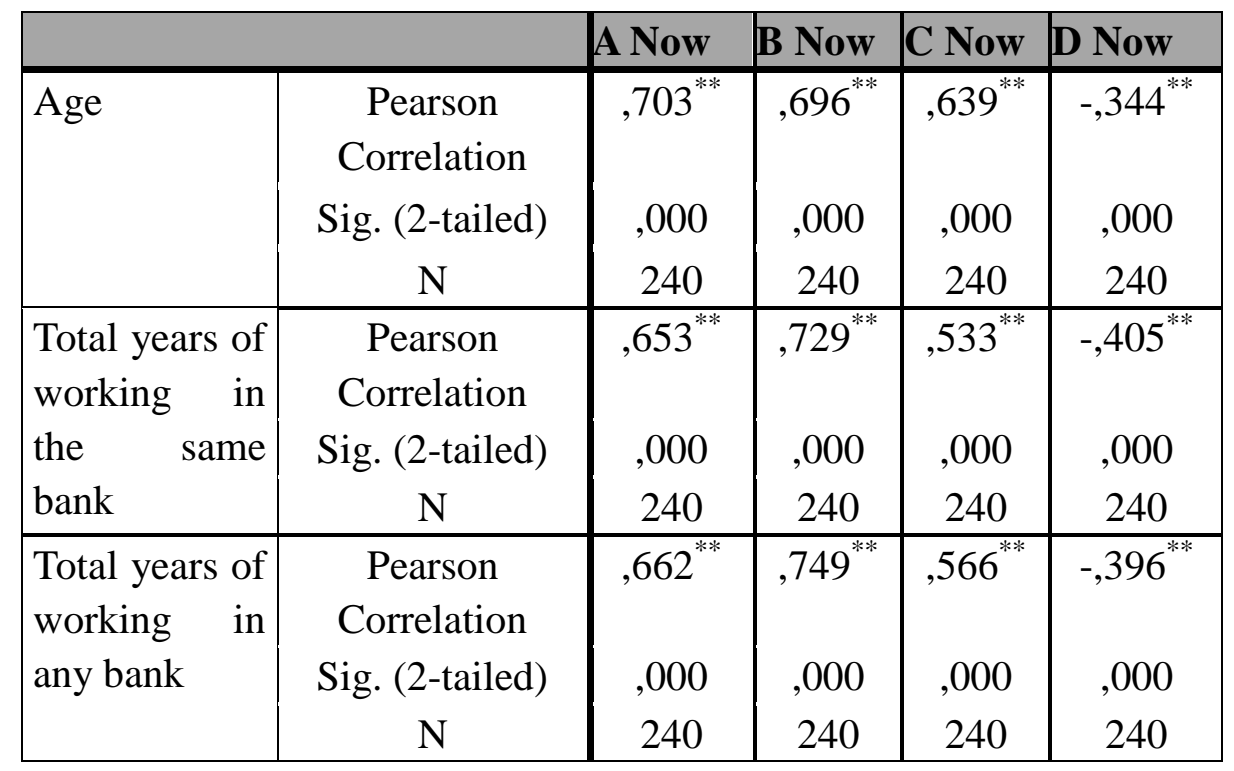

Additionally, it was found that there is statistically significant correlation (Pearson Correlation Coefficients) between the age of the participants and the preferred organizational culture that they chose, the total amount of years that these employees were working as employees in any bank and the preferred organizational culture that they chose and the total amount of years that they have been working in the same bank and the preferred 
organizational culture that they chose (Table 9).

For the preferred cultures it was found that there is a positive correlation between the age and cultures $\mathrm{A}(\mathrm{r}=0.146$ and $\mathrm{p}=0.023<0.05)$ and $\mathrm{B}(\mathrm{r}=0.785$ and $\mathrm{p}=0.000<0.01)$, which indicates that as the age increases the appeal of these cultures to the employees increases as well. Counter to the above it was found that there is a negative correlation between the age and cultures $\mathrm{C}(\mathrm{r}=-0.571$ and $\mathrm{p}=0.000<0.01)$ and $\mathrm{D}(\mathrm{r}=-0.571$ and $\mathrm{p}=0.000<0.01)$, indicating younger as someone is the more he/she desires the future cultures to be the cultures $\mathrm{C}$ and D (Table 9).

Similarly results were found and for the total years that someone has worked in the same bank, where the employees that have been working there for many years preferred cultures $\mathrm{A}$ $(r=0.413$ and $p=0.000<0.01)$ and $B(r=0.840$ and $p=0.000<0.01)$ and the employees that have been working in the same bang for a few years only, preferred cultures $\mathrm{C}$ $(\mathrm{r}=-0.749$ and $\mathrm{p}=0.000<0.01)$ and $\mathrm{D}(\mathrm{r}=-0.749$ and $\mathrm{p}=0.000<0.01) \quad$ The same resulted and for the total amount of years that someone has been working as a bank employee (in any bank). The employees that have greater experience and have been working for a long time preferred the cultures $\mathrm{A}(\mathrm{r}=0,440$ and $\mathrm{p}=0.000<0.01)$ and $\mathrm{B}(\mathrm{r}=0.841$ and $\mathrm{p}=0.000$ $<0.01)$, where the employees that haven't been working as bank employees prefer the cultures $\mathrm{C}(\mathrm{r}=-0.773$ and $\mathrm{p}=0.000<0.01)$ and $\mathrm{D}(\mathrm{r}=-0.773$ and $\mathrm{p}=0.000<0.01)$ (Table 8).

Table 9. Correlations between dominant preferred types of organizational culture with employees' age, total years of working in the same bank and total years of working in any

bank

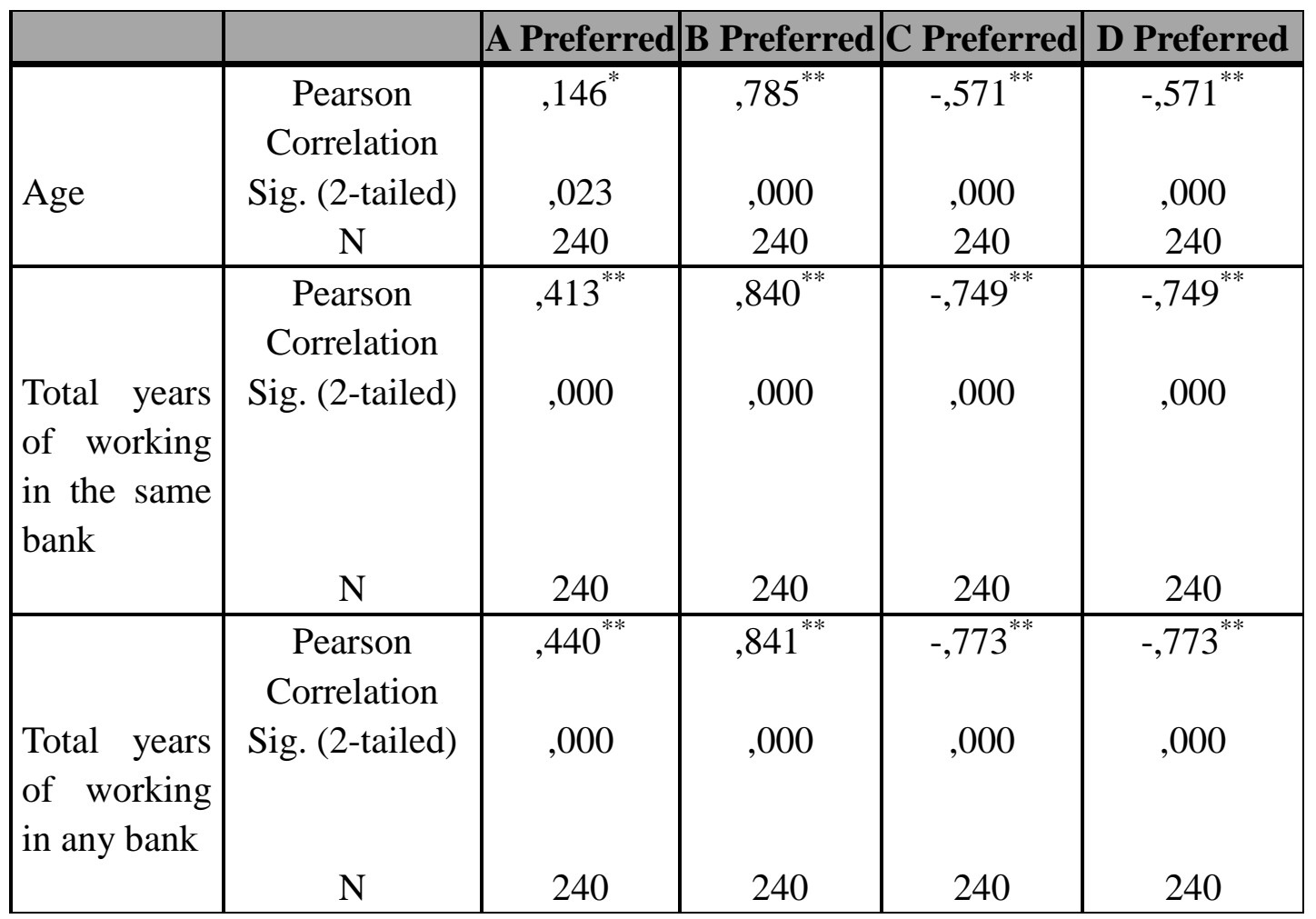




\section{Discussion}

The term "culture" in the frame of organizational analysis refers to interaction influences between the organizations and the cultural environment in which they are located. In contemporary societies and business markets, organizations and institutions have become distinctive from the special, unique cultures they have developed. In every occupational context, the culture is created through the actions of its founders, and the organization is gradually formed as a social group of people. Thus, it could be said that organizational culture is a social construct, as it happens with culture in general (Gjuraj, 2013).

The present study has shown that each employee's perspective of the culture (present and preferred), is formed by various factors such as age, position held and years of experience. More specifically, it was made clear that the dominant current type of organizational culture in Greek banking institutions is the Hierarchy type and the less common is the Adhocracy one. As for the preferred type, the Clan culture was found to be the most popular for the majority of employees, followed by the Adhocracy, the Market and the Hierarchy one.

Taking into consideration each factor of the organizational culture type separately, in terms of Dominant Characteristics the majority of employees reported that their organization is results-oriented and a major concern is getting the job done, while they would prefer them and their colleagues to be more risky and take more initiative. As for the Organizational Leadership, both the dominant current and the preferred leader were considered to exemplify coordinating, organizing, or smooth-running efficiency. In terms of Management of Employees, the current management style in Greek banking institutions seems to be characterized by security of employment, conformity, predictability and security in relationships. However, the majority of employees would prefer a management style of teamwork, consensus and participation.

When it comes to the factors that hold the organization together (Organization Glue), most employees reported that their working environment is characterized by formal rules and policies, while they would rather work in a place of loyalty and mutual trust. As for the Strategic Emphases, the majority of participants chose permanence and stability. However, the preferred strategies would focus on human development, high trust, openness and participation. Additionally, quite a big number of employees would prefer to work in a frame of new resources acquirement, creation and opportunity provision. In terms of the last factor, Criteria of Success, efficiency and low-cost production seem to be the dominant current features of contemporary Greek banking institutions, while employees would focus on human resource development, teamwork and commitment.

Therefore, a first conclusion of the study is that there is a significant difference between all aspects of current and preferred organizational culture types, except for Organizational Leadership, among employees of Greek banking institutions. The majority of employees would prefer to work in a more friendly environment, where mutual trust and informal relationships among colleagues are dominant, personal ambitions are taken into consideration and teamwork is rewarded. 
Another important finding of the study was that employees' perceptions of both current and preferred organizational culture type are affected by the position they hold in the specific organization. In particular, the majority of Managers, Assistant Managers and Clerks who took part in the study reported that the dominant current organizational culture type was the Hierarchy one, while the majority of Supervisors chose the Market type as dominant.

Apart from the first reported culture type, differences where found among the reported order of the rest culture types chosen by employees. In particular, Managers and Clerks believe that the current order of the four types is D, C, A, B, while the Supervisors think that is C, D, A, B. Thus, it can be said that Supervisors perceive their workplace as result-oriented and achievement-emphasized, whereas Managers and Clerks pay more attention to stability and control.

As for the preferred culture types, statistically significant differences were found among employees of different positions in almost every type, except for the adhocracy one. More specifically, Managers sorted the culture types with the following order C, B, D and A, where the corresponding order for Supervisors was C, B, A and D. When it comes to Clerks, they choose their preferred cultures as A, D, B, C. Therefore, it can be supported that Managers and Supervisors would prefer a more winning-oriented workplace, while Clerks would rather be more participating and able to promote their potential.

Taking into consideration the demographic characteristic of age, the hypothesis that there younger employees perceive the dominant organizational culture type in different ways than older ones was confirmed. In terms of current organizational culture type, age was positively correlated to almost every type of culture, apart from the Hierarchy one, with which it was negatively correlated. Thus, it could be assumed that older employees are more likely to perceive their working environment as highly controlled and stability-emphasized. This assumption might be explained by the fact that younger people are considered to be more prone to anxiety and feelings of incompetence. Considering the current financial crisis in Greece and the fact that hundreds of employees are either in danger of losing their job or forced to an early retirement, it comes as no surprise that younger bank employees reported that efficiency and smooth operations are important for their organization.

Analyzing correlations between age and preferred organizational culture types, positive correlations were found between age and the clan and the adhocracy culture types, while negative correlations were found between age and the market and the hierarchy culture types. This finding would mean that older employees prefer to work in a more friendly-family like and opportunity-providing environment, whereas younger employees prefer a more competitive an organized working frame. The findings about the factor of age confirm the previous work of other researchers, like Chen et al. (2008) and Kodzik (2009), who supported that employee's perceptions of organizational culture are likely to be influenced by age. However, those findings come to disagreement with the study of Allard (2010), who found that employees' age does not seem to affect the relation between the employee-organizational culture gap and performance.

As for the correlations between working experience and current organizational culture types, positive correlations were found between the perceptions of employees that have been working in the same bank for many years and every type of culture, apart from the Hierarchy 
one, with which employees' perceptions were negatively correlated. This finding implies that employees that have spent less time in a particular banking institution perceive it to be highly structured, stable and predictable, while older employees tend to pay attention to other characteristics, like teamwork and consensus.

When it comes to the preferred culture type, positive correlations were found between total years of working in the same bank and the clan and the adhocracy culture types, while negative correlations were found between total years of working in the same bank and the market and the hierarchy culture types. This finding would mean that employees that have spent more time in a particular banking institution prefer to work in a more friendly-family like and opportunity-providing environment, whereas employees who have spent less time prefer a more competitive an organized working frame.

The results were similar for the total years of working in any banking institution and the dominant current and preferred types of organizational culture. The findings about the factor of years of experience confirm those of Allard (2010), according to which the relation between the employee-organizational culture gap and performance tended to be stronger for employees with more employee longevity. Finally, the suggestions of Crumpacker and Crumpacker (2007) that managers should accept that employees are likely to bring their personal generational or age-based values to work are confirmed as well.

\section{Conclusion}

The present study makes a significant contribution to human relation practices by exploring the ways age, position held and years of experience influence perceptions of organizational culture in Greek banking institutions. As it was revealed, there was a significant difference between the organizations' culture and the culture preferred by the participants. Such mismatch should be taken into consideration, as many researches have revealed that it is likely to lead to decrease in job performance (Ojo, 2009), to job dissatisfaction (Lund, 2003) and job burnout (Belias et al., 2013). Additionally, differences between employees' preferred and current organizational culture are likely to affect job commitment and turnover intention (O'Reilly et al., 1991). For those reasons, employees' preferences should be measured, studied and utilized both in the frame of the specific organization they work in and in the frame of branches and national cultures. Assuring employee's well being will improve their performance and productivity and make organizations, institutions and companies more competitive, especially in times of financial crisis.

The results of the present study could be utilized in the development of internal and external marketing strategies of bank institutions in Greece and other countries. In this way, employees could become more close to each other, job committed and efficient, while institutions could become more tight and successful. However, further studies are needed to elucidate other factors that may influence an individual's perceptions of organizational culture, e.g. marital status, mental health etc. Such studies should take place both in local and in national level, so that the bank field in Greece is improved, becomes more profitable and ensures the prevention of turnover. 


\section{References}

Acar, A.Z., \& Acar, P. (2012). The Effects of Organizational Culture and Innovativeness on Business Performance in Healthcare Industry. Procedia-Social and Behavioral Sciences, 58, 683-692.

Banville, D., Desrosiers, P., \& Genet-Volet, Y. (2000). Translating Questionnaires and Inventories Using a Cross Cultural Translating Technique. Journal of Teaching in Physical Education, 19, 374-387.

Belias, D., \& Koustelios, A. (2013). Organizational Culture of Greek Banking Institutions: a Case Study. International Journal of Human Resource Management and Research, 3(2), 95-104.

Cameron, K.S., \& Quinn, R.E. (2006). Diagnosing and Changing Organizational Culture Based on the Competing Values Framework. The Jossey-Bass Business \& Management Series.

Chatman, J.A., Polzer, J.T., Barsade, S.G., \& Neale, M.A. (1998). Being Different Yet Feeling Similar: The influence of Demographic Composition and Organizational Culture on Work Process and Outcomes. Administrative Science Quarterly, 43, (4), 749-780.

Cox, T.H., Lobel, S.A., \& L. McLeod, P.L. (1991). Effects of ethnic group cultural differences on cooperative and competitive behavior on a group task. Academy of Management Journal, 34, 827-847.

Crumpacker, M., \& Crumpacker, J. (2007). Succession planning and generational stereotypes: Should HR consider age-based values and attitudes a relevant factor or a passing fad. Public Personnel Management, 39(4), 349-369.

Deal, T., Kennedy, A. (1982).Corporate Cultures. Penguin Books, First Publication by Addison Wesley 1982. In: Jones, G. (2008). Enhancing Due Diligence-Examination of the Organizational Culture of a Merger and Acquisition Test. Journal of Business \& Economics Research, 6(1), 11-16.

Denison, D., Lief, C., \& Ward, J.L. (2004). Culture in Family-Owned Enterprises: Recognizing and Leveraging Unique Strengths. Family Business Review, 17, 61-70.

Deshpande, R., \& Webster, F.E. (1989). Organizational Culture and Marketing: Defining the Research Agenda. The Journal Of Marketing, 53(1), 3-15.

Donnellon, A. (1993) Crossfunctional teams in product development: Accommodating the structure to the process. Journal of Product Innovation Management, 10, 377-392. 
Gjuraj, E. (2013). The importance of national culture studies in the organizational context. European Scientific Journal, 9(11), 160-180.

Hofstede, G. (1991). Cultures and Organizations: Software of the mind. CA: Sage: Beverly Hills.

Jones, G. (2008). Enhancing Due Diligence-Examination of the Organizational Culture of a Merger and Acquisition Test. Journal of Business \& Economics Research, 6(1), 11-16.

Kodzik, K. (2009). Asking the right questions to decode corporate culture. http://cultivatingcareers.com/2010/01/decoding-corporate-culture.

Lund, D. (2003). Organizational Culture and Job Satisfaction. Journal of Business and Industrial Marketing, 18(3), 219-236.

Nemeth, C. (1992). Minority dissent as a stimulant to group performance. In: S. Worchel, W. Wood, and J. Simpson (eds.), Group Process and Productivity, 95-111. London: Sage.

O'Reilly, C.A., \& Chatman, J. (1996). Culture as social control: Corporations, cults, and commitment. In: B. M. Staw and L. L. Cummings (eds.), Research in Organizational Behavior, 18, 157-200. Greenwich, CT: JAI Press.

O’Reilly, C.A., Caldwell, D.F., \& Barnett, W.P. (1989). Work group demography, social integration, and turnover. Administrative Science Quarterly, 34, 21-37.

O’Reilly, C.A., Chatman, J., \& Caldwell, D.F. (1991). People and Organizational Culture: A Profile Comparison Approach to Assessing Person-organization Fit. Academy of Management journal, 34, 487-516.

Ojo, O. (2008). Impact Assessment of Corporate Culture on Employee Job Performance. Business Intelligence Journal, 2(2), 388-397.

Ravasi, D., \& Schultz, M. (2006). Responding to Organizational Identity Threats: Exploring the Role of Organizational Culture. Academy of Management Journal, 49(3), 433-458.

Salopek, J.J. (2006). Leadership for a new age. Trands, 60(6), 22-23.

Schein, E.H. (1986). Organizational Culture and Leadership. Jossey-Bass: San Francisco.

Thomas, D.A., \& Ely, R.J. (1996). Making differences matter: A new paradigm for managing diversity. Harvard Business Review, 74, 79-90.

Tsui, A.S., Egan, T.D., \& O 'Reilly, C.A. (1992). Being different: Relational demography and organizational attachment. Administrative Science Quarterley, 37: 549-579. 


\section{Macrothink}

International Journal of Human Resource Studies

ISSN 2162-3058

Turner, J.C., Oakes, P.J., Haslam, S.A., \& McGarty, C. (1994). Self and collective: Cognition and social context. Personality and Social Psychology Bulletin, 20, 454-463.

Xenikou, A., \& Furnham, A. (1996). A Correlational and Factor Analytic Study of Four Questionnaire Measures of Organizational Culture. Human Relations, 49, 349-371.

Xiaoming, C., \& Junchen, X. (2012). A Literature Review on Organizational Culture and Corporate Performance. International Journal of Business Administration, 3(2), 29-37.

Zender, T.R., \& Lawrence, B.S. (1989). Organizational Demography: The differential effects of age and tenure distributions on technical communication. Academy of Management Journal, 32: 535-376. 